\title{
Leading by Example? ALA Division Publications, Open Access, and Sustainability
}

\section{Nathan Hall, Sara Arnold-Garza, Regina Gong, and Yasmeen Shorish}

This investigation explores scholarly communication business models in American Library Association (ALA) division peer-reviewed academic journals. Previous studies reveal the numerous issues organizations and publishers face in the academic publishing environment. Through an analysis of documented procedures, policies, and finances of five ALA division journals, we compare business and access models. We conclude that some ALA divisions prioritize the costs associated with changing business models, including hard-to-estimate costs such as the labor of volunteers. For other divisions, the financial aspects are less important than maintaining core values, such as those defined in ALA's Core Values in Librarianship.

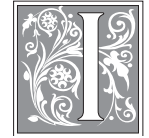

$n$ recent years, several ALA journals have explored alternative scholarly communication models, due to growth in electronic publishing and open access (OA) movements. These alternative models include moving to or adding electronic formats, allowing access to publications without subscription fees, or a combination of both.

This investigation analyzes scholarly communication business models in American Library Association (ALA) peer-reviewed academic journals through the aspects of pricing, access, and distribution. The five journals are Library Resources and Technical Services (LRTS), College E Research Libraries (CERL), Information Technology and Libraries (ITAL), Library Leadership \& Management (LLEM), and Reference E User Services Quarterly (RUSQ). We discuss financial and technical considerations for scholarly journals in transition to new distribution and access models and make an argument that association values demand OA models.

Nathan Hall is Assistant Director, Digital Imaging \& Preservation Services, in the Newman Library at Virginia Polytechnic Institute and State University; e-mail: nfhall@vt.edu. Sara Arnold-Garza is Research $\mathcal{E}$ Instruction Librarian in the Albert S. Cook Library at Towson University; e-mail: sarnoldgarza@towson. edu. Regina Gong is Manager of Library Technical Services E Systems at Lansing Community College Library; e-mail: gongr1@lcc.edu. Yasmeen Shorish is Associate Professor, Data Services Coordinator at James Madison University; e-mail: shorisyl@jmu.edu. All authors contributed equally to this article. (c) 2016 Nathan Hall, Sara Arnold-Garza, Regina Gong, and Yasmeen Shorish, Attribution-NonCommercial (http://creativecommons.org/licenses/by-nc/3.0/) CC BY-NC. 
ALA journals are changing their business models, joining a wider trend in publishing and knowledge distribution. ${ }^{1}$ Former production and distribution models are becoming financially less attractive, as printing and shipping costs rise and the number of subscribers decreases. ${ }^{2}$ The editorial boards of these journals, along with ALA's governance, face tough decisions about how to best serve members while maintaining the financial health of the association. Medium- and long-term planning must ensure new business models are sustainable. In this period marked by declining membership, ${ }^{3}$ change may alienate members who prefer existing models. Association journals must address these pragmatic challenges.

ALA as an advocacy organization and community of practice maintains a number of progressive positions stemming from a common "ethological approach," ${ }^{4}$ creating a dilemma. Librarians engage in research and advocacy in scholarly communication and intellectual freedom. The Association of College and Research Libraries (ACRL) maintains a listserv on scholarly communication. ALA identifies itself as an advocacy organization that values openness and supports OA, especially for federally funded research. ${ }^{5}$ ALA promotes "an equal commitment to the right of unrestricted access to information and ideas" regardless of the format or content of the work. ${ }^{6}$

Vandergrift and Bowley analyze copyright, OA policies, and publishing options in 111 library and information science (LIS) journals and argue that, while librarianship is linked to OA, many LIS journals remain behind paywalls. ${ }^{7}$ Their findings demonstrate a conflict between values and practice: the stated values of the profession lean toward OA, yet some stakeholders see OA as risky. Despite ALA's position on OA and intellectual freedom, changing business models for division publications appears to present a challenge.

This paper addresses a problem for professional associations, which struggle to balance commitments to the profession while ensuring financial sustainability. We seek to answer the following two questions: How have ALA's academic journals managed change in their scholarly communication models? Do these changes indicate a professional imperative toward open access? To address these questions, we review relevant literature, describe our approach, present our findings, and discuss the impact of these findings on the profession.

\section{Literature Review}

Previous studies have analyzed OA publishing within other academic disciplines and professional associations. ${ }^{8}$ These studies reveal numerous issues in the academic publishing environment, which are often inherent in the publishing models of commercial publishers, nonprofit institutional publishers, and nonprofit association publishers. While there is a body of literature associated with the business models and practices of each type, it is important to note that the findings that apply to one model are not generalizable to the other models. However, our review of the literature reveals two themes common among the models during transition: ways of adopting new technologies and ways of managing stakeholder expectations. Therefore, this section discusses findings from each of these models to demonstrate their similarities and differences in managing change.

Nonprofit institutional publishers have an academic mission, but they also operate within market-based constraints as defined by university administration. The Association of American University Presses (AAUP) Task Force on Economic Models for Scholarly Publishing describes changes in scholarly communications, including technological and cultural shifts brought about by the digital medium. ${ }^{9}$ The AAUP Task Force asserts that university presses, libraries, scholarly societies, publishers, and researchers are integral to the scholarly environment. These groups need to cooperate to maintain a vibrant 
and sustainable system, especially in a period of technological and cultural change. The authors describe business models in which stakeholders embrace multiple content types and forms of scholarly works, which depend on accessibility inherent in online and OA dissemination. The report concludes that no single business model replaces print.

Distinct from university press publishing, commercial academic publishers face different challenges due to their different mission. Their approach is based on a perception of market value for a scarce resource. Producing and selling high-quality journals generates profit. ${ }^{10}$ Several mainstream commercial publishers have embraced OA as a revenue stream, which has been more lucrative than disruptive for many firms. This revenue largely comes from business models in which authors pay fees to journals to publish their work as OA. ${ }^{11}$

Beverungen, Böhm, and Land conducted a critical analysis of for-profit academic publishing. ${ }^{12}$ Their main critique is that academic publishing appropriates resources when universities pay for the research, writing, reviewing, and editing of journals, which their libraries ultimately have to purchase.

This traditional journal publishing model creates significant challenges. As noted by Reinsfelder, departmental and disciplinary culture have greater influence than librarians on where faculty publish. ${ }^{13}$ Further, faculty researchers and administrators rely on publisher-owned metrics for evaluating the impact of faculty work. Reinsfelder also observes that publishers exert influence over faculty and librarians through restrictive copyright agreements and licenses for content that faculty must produce and librarians must purchase. ${ }^{14}$ Reinsfelder asserts that librarians and faculty researchers can only counter this pressure when working in a concerted effort to demonstrate disapproval by rejecting an undesirable product. ${ }^{15}$

Both commercial publishers and nonprofit academic associations have a common history of selling journals to generate revenue, though with different goals. Even with a nonprofit status, association journal publishing has long required sales revenue to sustain operations. New production and distribution technologies and shifts in stakeholder values have created opportunities and expectations for some scholarly associations to adopt a new distribution model. Yet it is difficult to move from a publishing model based on exchanges between consumers and producers to a model where sponsors or authors underwrite production, allowing producers to distribute content freely.

Association-published journals face different emerging challenges from commercial or institutional publishers. OA models come with risk, as illustrated by the suspension of Open Medicine, a journal unofficially affiliated with the Canadian Medical Association, which was managed for eight years by committed people with an incentive to disassociate their research from pharmaceutical intrusion into the editorial process. ${ }^{16}$ Their publication model relied on a few dedicated physicians who volunteered their time while also maintaining busy careers, and their value was in their editorial independence, unconnected to the official association body. Although there was a strong incentive based on personal conviction, which cannot be assigned a tangible or quantitative value, they did not have the support of a large institution to sustain their efforts. The freedom from bureaucracy gave them greater agility to move quickly to transition their journal, but it also hampered the long-term sustainability of their enterprise and was "chronically frustrating." 17 Their editorial work had social benefits, but it did not translate into resources such as labor and money that could have kept the journal operational. In short, they did not have teams of qualified volunteers seeking service opportunities and facilitating editorial succession, as official association publications would.

Another sustainability challenge for some association journals is the lack of an institutional home. A university can offer stability and sustainability with its diversified resources and infrastructure, when the mission of an association may not be a 
strong driving force for survival. McCormick and Skinner et al. discuss the skills that librarians can bring to publishing, illustrating how academic libraries show potential as publishing partners for association journals. ${ }^{18}$

Uncertain revenue streams are a challenge across publishing, but particularly in associations, where journal publishing may be a minor part of the organization's efforts and focus. Waltham finds that some editors of association-published journals are concerned that ceasing print production would reduce revenue, since a tangible product can be a major revenue source for some journals. Waltham's study examines the publishing and revenue models of eight humanities and social science association journals to determine whether OA is a sustainable model for this class of journal. In an analysis of revenues and expenses, Waltham found wide variance in funding structure and pricing with each academic association, ultimately concluding that OA funded by author or producer fees is not yet sustainable. ${ }^{19}$ Both ALA division journals and Waltham's sample face uncertainty about future revenue streams due to changes in delivery mechanisms. The journals Waltham studied produced concurrent print and online versions at the time of the survey. Their major sources of revenue included institutional print subscriptions and individual memberships. There are parallels for some ALA division journals, which have recently produced both print and online versions with revenue coming from institutional and individual subscriptions. ALA journal editorial boards share an uncertainty about revenue. ${ }^{20}$ When managing change for academic journals produced by a nonprofit association, uncertainty about revenue is clearly a barrier due to concerns about financial sustainability.

Replacing revenues lost by changes to production and access models presents another issue for association-published journals, provoking questions about incentives for membership. McSean and Jakobsson describe this challenge to managing change in association-published journals. ${ }^{21}$ In 2005, due to declining membership and revenues, the European Association for Health Information and Libraries (EAHIL) restructured its organization and benefits, including changing access to the Journal of the European Association for Health Information and Libraries (JEAHIL). EAHIL dubbed the transformation the "Open Access solution" due to its new dependence on web-based operations along with the removal of membership fees in Council of Europe member countries. The journal became entirely available online, and content was only printed on request. Costs were borne by advertising and sponsorship rather than by subscriptions. The change resulted in significant increases in advertising revenue for JEAHIL because of its broader distribution - a result of the removal of membership barriers. Like EAHIL, ALA divisions face financial and structural difficulties associated with declining membership. ${ }^{22}$ While changes to the access and revenue models for a scholarly journal may be necessary, circumstances are complicated when access to the journal is a benefit of membership and when there are concerns about declining membership.

One way to help association members adapt is through detailed and transparent communication about the reasons for change and the technical aspects of how the change will affect the journals and its readers. The American Anthropological Association (AAA), which adopted an OA model for its journal, is an example of how an association can communicate change to readers. In 2012, the Society for Cultural Anthropology (SCA), a Section of AAA, responded to an open call from AAA and decided to transition to an OA publication. Timothy Elfenbein, managing editor for Cultural Anthropology, gives a detailed account of the implementation including challenges and considerations..$^{23}$ Given that the move to OA involved leaving a contract with Wiley-Blackwell and setting up a new platform with Open Journal Systems (OJS), the process was complex and required a large amount of planning. Elfenbein outlines the production process, metadata processing, publishing platform, content manage- 
ment, and administration. By transparently and thoroughly discussing these details, Cultural Anthropology demonstrates how communication and planning supported an academic association's move from a commercial publisher to OA publishing. These are important lessons for editors, governance bodies, and members of ALA divisions as they consider scholarly communication business models for their academic journals.

\section{Methods}

Through an analysis of documented procedures, policies, and finances of five ALA division journals, we compare business and access models, revealing differences in the transitional activities and results for journals that have implemented or considered a move to OA. We analyzed these organizations, which are related yet distinct, because they were all addressing the same issue for the same apparent reasons. This is similar to an instrumental case study in that our purpose is to provide insight into broader issues of scholarly communication, electronic publishing, and OA. ${ }^{24}$ This study includes LRTS, $C \mathcal{E} R L, I T A L, R U S Q$, and LLEM. These titles are all the peer-reviewed ALA division journals, which have undergone or contemplated changes to their business models in recent years. The changes include either a transition away from a print format, or a transition to an OA model, or both.

We reviewed LRTS, RUSQ, CERL, ITAL, and LLEM to make comparisons in circulation, editorial policies, revenues, and expenses. Most of the information to make these comparisons comes from the journals' websites or in published statements from their editors. Some of the financial information appears in reports by ALA division task groups. For example, we made extensive use of data found in the "Final Report of the ALCTS Publishing Review Task Group," and supplementary materials, made available to us through special request. ${ }^{25}$ These reports, when available, were produced between 2011 and 2013, indicating that the academic journals of most ALA divisions were concurrently addressing the same issues. Finally, we also received some information through personal communication with journal editors.

We compared the practices of the five selected journals to derive categories that illustrate similarities and differences. The categories include content, submission, access, hosting, revenue, and expenses and are explored in the findings. We also conducted a comparative analysis of the transition process for each of the journals. The themes and the comparative analysis together describe how the five journals managed or contemplated transition and what each learned from the experience.

We have identified several limitations to this study. Some of the documents we analyzed include internal financial documents such as budgets and expense reports. The first limitation is that these data were sometimes not finalized, and some of the figures were later revised, though they were the best available at the time of data collection. The second limitation is that we received some information through informal correspondence with editors, and some editors were more conservative than others about what kinds of information and how much information they were willing to share. As a result, there was no basis for comparison on some aspects. The third limitation is that some of these journals are still in transition, or it is too early to assess the impact of the transition. A fourth limitation is that all data come from official documents, published sources, and personal communication with editors or other administrators. We did not seek the perspectives of authors, readers, or association members, which means that this paper presents findings based on a limited range of perspective. Due to these limitations, readers should view this as a starting point for a discussion on the business of the scholarly communication of ALA, to demonstrate the similarities between ALA's peer-reviewed journals and to determine if-based on the scholarly communication practices of ALA publications - open access is a professional imperative. 


\section{Findings}

As seen in table 1, ALA Division Publication Details, the journals in the sample share similarities. Each of them includes peer-reviewed content, along with editorials and editor-reviewed content. Four of the five journals, CERL, RUSQ, ITAL, and LLEM, also accept advertising. Although there are differences in publication schedule, the journals as a group are quite similar to each other.

\begin{tabular}{|l|l|l|l|l|l|l|}
\hline \multicolumn{7}{|c|}{ TABLE 1 } \\
\hline Journal Title & $\begin{array}{l}\text { ALA } \\
\text { Division }\end{array}$ & Frequency & Format & Access & $\begin{array}{l}\text { Peer } \\
\text { Review? }\end{array}$ & Platform \\
\hline $\begin{array}{l}\text { College \& } \\
\text { Research } \\
\text { Libraries } \\
\text { (C\&RL) }\end{array}$ & ACRL & Bimonthly & $\begin{array}{l}\text { Online } \\
\text { only since } \\
\text { January } \\
2014\end{array}$ & Gold OA & Yes & HighWire \\
\hline $\begin{array}{l}\text { Information } \\
\text { Technology and } \\
\text { Libraries (ITAL) }\end{array}$ & LITA & Quarterly & $\begin{array}{l}\text { Online only } \\
\text { since March } \\
2012\end{array}$ & Gold OA & Yes & OJS \\
\hline $\begin{array}{l}\text { Library } \\
\text { Resources } \\
\text { and Technical } \\
\text { Services (LRTS) }\end{array}$ & ALCTS & Quarterly & $\begin{array}{l}\text { Online } \\
\text { only since } \\
\text { January } \\
2015\end{array}$ & $\begin{array}{l}\text { Green } \\
\text { OA }\end{array}$ & Yes & OJS \\
\hline $\begin{array}{l}\text { Library } \\
\text { Leadership and } \\
\text { Management } \\
\text { (LL\&M) }\end{array}$ & LLAMA & Quarterly & $\begin{array}{l}\text { Online only } \\
\text { since Winter } \\
2010\end{array}$ & Gold OA & Yes & OJS \\
\hline $\begin{array}{l}\text { Reference and } \\
\text { User Services } \\
\text { Quarterly } \\
\text { RUSQ) }\end{array}$ & RUSA & Quarterly & $\begin{array}{l}\text { Online only } \\
\text { since Fall } \\
2011\end{array}$ & $\begin{array}{l}\text { Green } \\
\text { OA (and } \\
\text { RUSA } \\
\text { members) }\end{array}$ & Yes & OJS \\
\hline
\end{tabular}

The article submission process for authors is also similar among the journals. ITAL, LRTS, LLEM, and CERL use automated manuscript management services, whereas RUSQ authors submit via e-mail. Submissions for CERL, RUSQ, LRTS, and ITAL go through double-blind review, whereas LLEM authors may choose to submit through a peer review or an editorial review process. Rights agreements among journals vary. For CERL and ITAL, authors retain copyright. LLEM specifically publishes works under a Creative Commons Attribution License, with authors retaining copyright. LRTS authors have a choice to assign copyright to ALA while retaining certain rights or to keep copyright and licensing certain rights to ALA. RUSQ authors have the option of signing a limited license or a full agreement form.

\section{Access}

LLEM, ITAL, and CERL provide unrestricted access to published content. In February 2011, $L L \mathcal{E} M$ was made available online to anyone, with no restrictions. ${ }^{26}$ ITAL became a freely available online journal in March 2012, adopting an OA model to embrace innovation in scholarly technologies, explore additional publication possibilities, and make a statement that they believe in the benefits of OA to scholarly work. ${ }^{27} C \mathcal{E} R L$ became OA in April 2011 following the passing of a resolution by the ACRL Board of Directors in January $2011 .^{28}$ 
LRTS and RUSQ have green OA policies, which means that authors can share their articles in repositories. LRTS ceased print publication with its October 2014 issue, and became online only for members and paying subscribers starting with the January 2015 issue. ${ }^{29}$ New issues of RUSQ are available online to individual, institutional, and organizational members of the Reference \& User Services Association (RUSA) and to paying subscribers. RUSQ provides free public access to its archive of back issues through J-STOR.

Thus, three of the journals have already transitioned to gold OA models, meaning the journal makes the articles freely available. LRTS is in a transitional phase, moving to a gold OA policy from a green OA policy, meaning the journal does not make the articles freely available but allows the authors to do so. ${ }^{30} \mathrm{RUSQ}$ is the only journal in the sample that is not on a gold OA policy and has no current plans to change.

\section{Platforms}

Each journal in the sample uses a publishing platform to manage and disseminate content. ITAL previously used a combination of ALA Production Services for editorial management and the Library Information Technology Association (LITA) website as a platform for hosting. It stopped using these services and took advantage of institutional sponsorship through OJS hosted by Boston College. LLEM is hosted by the Texas Digital Library (TDL), a multiuniversity consortia repository, which hosts OA journals using OJS and manages some of the editorial and publication processes. CERL uses a contracted service called HighWire Press, an e-publishing platform associated with Stanford University. LRTS used MetaPress as the e-publishing and hosting platform until March 2015 when ALA canceled the MetaPress contract and Association for Library Collections \& Technical Services (ALCTS) Executive Director Keri Cascio announced on the ALCSTCentral listserv that LRTS would contract with OJS. RUSQ also used MetaPress as its hosting platform until March 2015, though ALA announced in May 2015 that it had moved, along with other journals to OJS. ${ }^{31}$

\section{Revenue \& Expenses}

Each of the journals in the sample is funded in a variety of ways, including subscriptions, advertising, and membership dues. RUSQ revenues come from advertising, memberships, subscriptions to nonmembers, as well as sales of individual articles within the two-year embargo. LRTS has historically received revenue through personal and institutional subscriptions as well as advertising. LLEM has considered advertising as a potential, though unrealized, revenue source. ITAL's revenue sources include association memberships, institutional subscriptions, advertising, and licensing content to EBSCO. CERL's only source of revenue is advertising. ${ }^{32}$

The sampled journals had similar expenses, including editorial stipends, and some production and publishing costs through contracted hosting services or through ALA Production Services. All five journals pay editorial stipends, which mostly support the editor's travel to meetings. LLEM also has occasional expenses for contract work for services such as improving website functionality and appearance. Copyediting, proofreading, formatting, graphic design, and workflow facilitation are conducted by LLEM coeditors as a cost-saving measure, but this results in significant workload for these volunteers. ITAL's regular expenses include hosting, production, and software. After ceasing print publication, expenses for publishing ITAL shrank to just 5.8 percent of the previous annual amount, according to an internal committee report. ${ }^{33} C \mathcal{E} R L^{\prime} \mathrm{S}$ regular expenses include hosting through HighWire Press, production, and software. ${ }^{34}$ RUSQ's regular expenses included a fee charged by MetaPress for each published article, until it moved to OJS, recently enough that any potential savings are not yet 
publicized. ALA Production Services provides RUSQ's copyediting, proofreading, and composition. Other one-time expenses included a setup fee with MetaPress and a 2011 project to convert back issues from print to digital format. Since ceasing print production in 2011, RUSQ's annual deficit is approximately 50 percent smaller than when it was a print journal. ${ }^{35}$ Expenses for LRTS include editorial and other operating expenses. Carolyne Myall, former ALCTS president, states that "even excluding printing and mailing costs ... production of LRTS requires $\$ 40,000$ annually" and that membership dues are not used to fund production of the journal. ${ }^{36}$

\section{Transition}

CERL's transition to an electronic-only, OA model occurred in two stages: ACRL first changed CERL's publishing model to OA at the ALA 2011 Midwinter Conference, and the division later decided at the ALA 2012 Annual Conference to cease print production and move to an exclusively online format. The transition process began with the ACRL Budget and Finance Committee convening a work team to review analyses on the potential impact of the proposed changes and then recommending action. ${ }^{37}$ Each initiative was considered independently. The work team included the CERL editor, members of the Budget and Finance Committee, the Publications Coordinating Committee, the Editorial Board of CERL, the Scholarly Communications Committee, and the Membership Committee. ACRL surveyed its membership, and their findings demonstrated general consensus that moving to an online format was a logical next step. The survey findings also indicated that the proposed format change would not have any impact on their membership status. ${ }^{38}$

The ACRL leadership learned several lessons from the transition process. Cynthia Steinhoff, Chair of the ACRL Board and Finance Committee, noted that the costs of producing an exclusively electronic journal were not immediately apparent in transitioning the journal. She reported that advertising revenue for an online version of a journal is typically lower than revenue for a printed version, and, in addition to the hosting fees, there are labor costs for formatting the text for the hosting platform. However, savings made on paper, printing, and postage can be applied to the other production costs. Finally, Steinhoff highlighted the importance of planning the journal's transition well in advance, allowing sufficient time to communicate the decision to members. It also allowed all paid subscriptions to expire before the change, minimizing refunds to subscribers for issues that will never be printed. ${ }^{39}$

ITAL became an OA online journal through a stepped process. The editorial board conducted a 2009-2010 survey where 60 percent of respondents (mostly LITA members) were in favor of ITAL becoming OA. The LITA Publications Committee also conducted an analysis of publishing options and issued a report to the LITA Board in January 2011. ${ }^{40}$ The report analyzed upfront costs of implementing an electronic-only journal, the continuing costs of supporting the platform, the annual cost savings of a switch to an electronic format, and the anticipated loss of subscription revenue. Among the various platforms considered, ITAL selected OJS.

In this transition, LITA decided to abandon the idea of ITAL as a source of revenue. LITA's goal for the transition was to make ITAL as close to revenue-neutral as possible. While subscription revenues were declining, production costs were not. Revenue losses were associated with external economic factors; it was easier to improve financial sustainability by changing the journal's business model to reduce expenses than to generate new revenue. LITA projected that the transition would significantly reduce production costs and editorial expenses associated with layout. LITA also projected that a decrease in revenue due to loss of subscriptions and advertising income would accompany these savings. ITAL completed the transition with its first OA, electroniconly issue of ITAL in March 2012. 
LLEM completed its transition to an online journal in winter 2009 , and the electroniconly format began with volume 24 in 2010, as planned. ${ }^{41}$ Since 2007, LLEM had been published as a web-accessible PDF of the print version for LLAMA members only. The board recognized the need for a marketing plan to minimize the loss of subscribers when the print version became unavailable. Specifically, they discussed options to prevent anticipated loss of membership revenue associated with transition to OA. ${ }^{42}$ Some options under consideration were to offer delayed access to nonmembers or to make a subset of content accessible to nonmembers, although no restrictions were adopted.

The organization's leadership viewed the conversion as an opportunity for reinvigorating sponsorship and advertising. In addition, the announcement also reflected LLAMA's professional ethics: "the editors of Library Leadership \& Management and the leadership of LLAMA have embraced open access in a very real albeit somewhat risky effort. We do so in order to model those values that we advocate, to back up our words with action. In making the decision to go open access, we alone take the risk, by turning away from a traditional and practiced publishing model." ${ }^{43}$ By the end of 2011, LLEM successfully published its first OA volume, migrated all previous volumes to online and $\mathrm{OA}$, and implemented a new peer-review process and editorial review board. The journal also began publishing multimedia files along with the rest of its content.

RUSA previously published RUSQ in both print and digital formats but ceased print production in 2011. The digital version (RUSQ Online Companion) was free during the transition period but there was not an official OA policy. After print production ceased, RUSA had to attract new advertisers to compensate for lost advertising revenue associated with the print version of RUSQ.4 While the transition appeared to result in loss of subscriptions to the journal, RUSA membership remained stable, and the savings in ceasing print production substantially offset the financial loss from dropped subscriptions. Paper and postage previously comprised 46 percent of the production budget, and the transition drastically reduced the annual deficit by 52 percent from FY2010 to FY2012.

LRTS' transition to electronic-only started in August 2011 when the ALCTS Board appointed a task force to examine, recommend strategic directions of, and revitalize the division's publishing program. Among the charges was to identify sustainable methods to secure LRTS's financial position. In July 2012, the ALCTS Publishing Review Task Force completed its final report, which includes an environmental scan of the publishing environment, a proposed vision and mission for ALCTS publishing, and recommendations for revitalization. ALCTS commissioned a 2013 Emerging Leaders group to investigate sustainable financial models for LRTS. The Emerging Leaders project proposed three models that could help LRTS improve financial stability: an ejournal with a print-on-demand option, a subscription-based e-journal with no print, and an OA e-journal. ${ }^{45}$

In the ALCTS Board of Directors meeting during the 2014 ALA Midwinter, the Board approved a motion to cease print publication of LRTS beginning with volume 59, number 1 (the January 2015 issue). An open letter to ALCTS members and LRTS subscribers announced that this move would generate "considerable savings by eliminating printing and mailing costs." ${ }^{46}$ For the first time in many years, ALCTS projected a positive net figure for LRTS due to reduction in expenses. ${ }^{47}$

The journals in the sample all had to make decisions about hosting as they moved to electronic publishing. Each division had to consider who should host their journal and why. Interestingly, each division had chosen a different hosting venue before some moved to OJS when ALA made this solution available in 2015. CERL pays for a third-party hosted service. LLEM and ITAL are each hosted by separate external institutional sponsors. After exhaustive internal discussions, ALCTS migrated LRTS 
from Metapress to OJS in a coordinated effort with other ALA division journals. RUSA did the same for RUSQ, moving from Metapress to OJS with ALA.

\section{Discussion}

This article sought to answer how ALA's academic journals manage change in their scholarly communication models, as well as how ALA scholarly publications have addressed financial sustainability issues. Although the data from the experiences of ALA journals are provisional, it is useful to consider them in context with the experiences of other association journals. The findings in this study concur with the reviewed literature, and together they expose key considerations when transitioning a journal to OA.

One notable finding of this study supported by other research concerns the cost of electronic publishing and OA. Elfenbein notes several aspects of journal production for consideration, including copyediting, layout, file conversion, content management, metadata management, administration of the publishing platform, and administration of vendor contracts for outsourced services, some of which are present when producing a print version as well..$^{48}$ In spite of these costs, RUSA cut their annual deficit in half when they ceased print production while maintaining subscription-based and members-only access, demonstrating that the costs in electronic publishing were offset by the savings in eliminating print and mailing expenses. Naturally, any estimated savings in transitioning a journal to electronic-only dissemination and OA depend in part on the previous business model and financial situation of each journal. While it would be useful to have such detailed data regarding the financial impact of the transition to OA from all the journals we studied, financial data is not uniformly publicly available, limiting our ability to broadly analyze the impact.

In several cases, stakeholders for ALA journals were concerned about loss of revenue in changing business models. As noted above, since journal access was formerly a membership benefit, some editors voiced concern that membership, and accompanying dues income, could decline if journal access was free. In hindsight, it appears that revenue loss was not as bad as feared. Given the complexity of external economic forces affecting journal revenue streams, it is difficult to determine what effect the transitions had on revenue from memberships or subscriptions. Since membership has consistently declined across ALA, additional study is needed to determine how many division memberships were dropped because the journal transitioned to an open access model.

This paper also notes that some journals identified and sought input from key stakeholder groups through surveys and governance procedures to support decision making. For ALCTS, ACRL, and LITA, it was important to consider the attitudes of the association membership, and to give association governance a voice through formal studies and official reports. These internal investigations explored how invested the membership and editorial boards are in the status quo. Each of these processes involved different stakeholders. ALCTS and LITA, for example, involved their respective governance structures, whereas $L L \mathcal{E} M$ leadership made the decision, stating "we alone take the risk." 49

Finally, transition to electronic-only production and transition to OA were sometimes considered separately. While electronic-only publication may reduce costs and improve access, that alone may not make OA sustainable because electronic production can introduce other costs. Divisions should consider their existing structural and financial commitments when evaluating each component of the model, since relative cost savings with an electronic-only publication are not always the driving factor in a journal's decision to move to OA.

The experiences of these journals provide lessons for other association-published journals. In contemplating a transition, each journal faced a distinct set of challenges 
based on its current or prior business model and on the culture of the discipline or membership.

\section{Conclusion}

Some ALA divisions prioritized the costs associated with changing business models, including hard-to-estimate costs such as the labor of volunteers. For other divisions, the financial aspects of the business model were less important than maintaining core values, such as those defined in ALA's Core Values in Librarianship.

As noted in the literature review, SCA documented and published many details of Cultural Anthropology's transition to OA..$^{50}$ This kind of transparency may help reduce anxiety for other editorial boards and membership communities exploring OA. For associations considering this option for ethical reasons, it is in their interest to give detailed accounts to manage change and advance that ethical position among their own membership. Transparency in change management is also useful for demonstrating the feasibility of this change.

While each journal operates in a different context, there are some comparable factors. As peer-reviewed journals that exist under the wider umbrella of ALA, their readership and editorial boards share some basic cultural traits and professional credentials. Further, the individuals are ALA members; therefore, they either tacitly or actively advance the association's ethics and values. The Core Values of Librarianship advocate barrier-free access to information, yet the business models of commercial journals create barriers to information access. ${ }^{51}$ The Core Values call for fostering the aspirations of others seeking entrance into the profession. It is difficult to do this with paywalls in place. The Core Values promote libraries as an essential public good in democratic societies and advocate for library resources to be freely and equally accessible to all users. They likewise urge caution in privatizing library services. Librarians could extend the spirit of the core values to their peer-reviewed scholarship. While a professional journal may not be a public good in the same way a publicly supported library is, librarianship has applied a set of values to the whole profession. It is thus incongruous not to apply the same essential values to the scholarly communication of librarianship. A library association journal business model that is not OA is contrary to ALA's Core Values.

There is growing momentum in the academic library community to address this contradiction. Vandergrift \& Bowley, along with some on the ACRL Scholarly Communication listserv, question the profession's reluctance to "walk the talk" when it comes to publishing in OA journals. ${ }^{52}$ At the time of this writing, the ACRL Research and Scholarly Environment Committee is drafting a policy statement to the ACRL Board regarding the scholarship of academic librarians and OA. ${ }^{53}$ The Core Values and the community's acknowledgement of ethical inconsistencies in publishing models serve as indicators of professional expectations.

A major challenge to consider in transitioning a journal to $\mathrm{OA}$ is balancing the values of librarianship with the pragmatism of managing a long-established and respected publication. While a paywall acts as a barrier to journal content and the base of knowledge that librarians develop, association governance and journal editorial boards are stewards, meant to ensure the sustainability of their organizations. Transitioning to OA comes with a cost, as demonstrated by ITAL, LLEM, CERL, and LRTS. While these journals have successfully managed a transition to OA, it is too early to know whether their new business models are sustainable. It is clear, however, that, for these ALA divisions, print production had become financially unsustainable while paywall access had become ethically unacceptable. ${ }^{54}$ Change was inevitable.

Considering the core values of librarianship, there should be no question of whether or not an ALA journal should be OA. In light of the costs and risks listed above, however, 
there should be serious consideration of how to financially sustain an OA journal in a way that serves the profession while maintaining rigor, editorial independence, and production values. Cockerill and Mangiafico \& Smith note that all models, including print, are potentially sustainable once it is decided who ultimately pays - for example, the library as host, the library as subscriber, or the member through dues. ${ }^{55}$ External factors, such as market forces in commercial models, or financial solvency in institutional sponsorship models, can influence the sustainability of any chosen model. Commercial journals break even or record a profit in part because the academic community provides the labor and it pays for journals through library budgets. Associations must consider whether or not a journal should be a revenue source and how that decision advances the profession. There are tradeoffs with any model; but, ultimately, the decision to select a business model is not one of sustainability as much as how best to meet the expectations of the members of ALA.

\section{Notes}

1. Christine L. Borgman, From Gutenberg to the Global Information Infrastructure: Access to Information in the Networked World (Cambridge, Mass.: MIT Press, 2000); Rob E. Kling and Ewa S. Callahan, "Electronic Journals, the Internet, and Scholarly Communication," in Annual Review of Information Science and Technology, ed. Blaise Cronin (Medford, N.J.: Information Today, 2003), 127-77.

2. "Finding a Way: Moving from Open Access Principle to Practice," ACRL Publications, available online at www.ala.org/acrl/publications/oafaq [accessed 13 October 2015].

3. "ALA's Membership Statistics by Division, 2000-Present," American Library Association, available online at www.ala.org/membership/membershipstats_files/divisionstats [accessed 17 October 2015].

4. Blaise Cronin, The Hand of Science: Academic Writing and its Rewards (Oxford, U.K.: Scarecrow Press, 2005).

5. "Libraries and the Internet Toolkit," American Library Association, available online at www.ala.org/advocacy/intfreedom/iftoolkits/litoolkit/openaccess [accessed 8 July 2015].

6. Intellectual Freedom Manual, ed. Candace D. Morgan (Chicago: American Library Association, 2010), xvii.

7. Micah Vandegrift and Chealsye Bowley, "Librarian, Heal Thyself: A Scholarly Communication Analysis of LIS Journals," In the Library with the Lead Pipe (Apr. 23, 2014), available online at www.inthelibrarywiththeleadpipe.org/2014/healthyself/ [accessed 30 June 2015].

8. Timothy W. Elfenbein, "Cultural Anthropology and the Infrastructure of Publishing," Cultural Anthropology 29, no. 2 (2014): 288-303, doi:10.14506/ca29.2.06; Mary Waltham, "The Future of Scholarly Journal Publishing among Social Science and Humanities Associations: Report on a Study Funded by a Planning Grant from the Andrew W. Mellon Foundation," Journal of Scholarly Publishing 41, no. 3 (2010): 257-324, available online at https://muse.jhu.edu/article/379028/pdf [accessed 27 July 2016].

9. Association of American University Presses Task Force on Economic Models for Scholarly Publishing, Sustaining Scholarly Publishing: New Business Models for University Presses (New York: Association of American University Presses, 2011), available online at www.aaupnet.org/images/ stories/documents/aaupbusinessmodels2011.pdf [accessed 30 June 2015].

10. Paolo Mangiafico and Kevin L. Smith, "Reason, Risk, and Reward: Models for Libraries and Other Stakeholders in an Evolving Scholarly Publishing Ecosystem," Cultural Anthropology 29, no. 2 (2014): 216-35, doi:10.14506/ca29.2.03.

11. Stephen Bosch and Kittie Henderson, "Whole Lotta Shakin' Goin' On: Periodicals Price Survey 2015," Library Journal (Apr. 23, 2015), available online at http://lj.libraryjournal.com/2015/04/ publishing/whole-lotta-shakin-goin-on-periodicals-price-survey-2015 [accessed 30 June 2015].

12. Armin Beverungen, Steffen Böhm, and Christopher Land, "The Poverty of Journal Publishing," Organization 19, no. 6 (2012): 929-38, doi:10.1177/1350508412448858.

13. Thomas L. Reinsfelder, "Open Access Publishing Practices in a Complex Environment: Conditions, Barriers, and Bases of Power," Journal of Librarianship and Scholarly Communication 1, no. 1 (2012): eP1029, doi:.10.7710/2162-3309.1029.

14. Ibid.

15. Ibid. 
16. Claire Kendall, James Maskalyk, and Anita Palepu, "Closing Open Medicine," Open Medicine 8, no. 4 (2014): e147, available online at www.openmedicine.ca/article/view/654/572 [accessed 30 June 2015].

17. Ibid.

18. Monica McCormick, “Toward New Model Scholarly Publishing: Uniting the Skills of Publishers and Libraries," in Getting the Word Out: Academic Libraries as Scholarly Publishers, ed. Maria Bonn and Mike Furlough (Chicago, Ill.: Association of College \& Research Libraries, 2015), available online at www.ala.org/acrl/sites/ala.org.acrl/files/content/publications/booksanddigitalresources/digital/9780838986981_getting_OA.pdf [accessed 15 June 2015]; Katherine Skinner, Sarah Lippincott, Julie Speer, and Tyler Walters, "Library-asPublisher: Capacity Building for the Library Publishing Subfield," Journal of Electronic Publishing 17, no. 2 (2014), doi:10.3998/3336451.0017.207.

19. Waltham, "The Future of Scholarly Journal Publishing," 275-77.

20. Wendi Arant Kaspar, "Walking the Talk: An Editor's Comments on Open Access," Library Leadership \& Management 25, no. 1 (2011): 1, available online at https://journals.tdl.org/llm/index. php/llm/article/view/1863/1624 [accessed 9 January 2015].

21. Tony McSean and Arne Jakobsson, "The Open Access Association? EAHIL's New Model for Sustainability," Health Information E Libraries Journal 26, no. 4 (2009): 316-21, doi:10.1111/j.14711842.2009.00843.x.

22. "ALA's Membership Statistics by Division, 2000-Present," available online at www.ala. org/membership/membershipstats_files/divisionstats [accessed 30 June 2015].

23. Elfenbein, "Cultural Anthropology," 288-303.

24. Sharan B. Merriam, Qualitative Research: A Guide to Design and Implementation (San Francisco, Calif.: Jossey-Bass, 2009), 48.

25. ALCTS Publishing Review Task Group, Final Report (July 28, 2012).

26. Pixey Mosley and Wendi Arant Kaspar, "Editors Introduction," Library Leadership E Management 25, no. 1 (2011): 1, available online at https://journals.tdl.org/llm/index.php/llm/article/ view/1956/1331 [accessed 30 June 2015].

27. Colleen Cuddy, "President's Message: Open Access/Open Data," Information Technology and Libraries 31, no. 1(2012): 2, doi:10.6017/ital.v31i1.1927.

28. Joseph Branin, "College and Research Libraries Goes Fully Open Access," College E Research Libraries 72, no. 2 (2011): 109, doi:10.5860/0720108.

29. Norm Medeiros, "eLRTS: An Old Friend in New Dress," Library Resources E Technical Services 58, no. 4 (2014): 218, doi:10.5860/lrts.58n4.218.

30. "ALCTS Board Approves Statement on Open Access," ALCTS News (June 30, 2014), available online at www.ala.org/alctsnews/features/openaccess14 [accessed 9 January 2015].

31. "New Platform for ALA's Online Journal Content," ALA Publishing, available online at www.ala.org/news/press-releases/2015/05/new-platform-alas-online-journal-content [accessed 9 January 2015].

32. College \& Research Libraries, Online Product Advertising Rates and Information (Chicago, Ill.: Association of College and Research Libraries, 2015), available online at www.ala.org/acrl/sites/ ala.org.acrl/files/content/publications/journalsandmagazines/crljournal/JRNL_ratecard_2015.pdf [accessed 10 July 2015].

33. Report from LITA Publications Committee on Issues Related to ITAL Moving to Electronic Only Format and/or Open Access (Jan. 1, 2011).

34. Cynthia Steinhoff, e-mail correspondence, March 5, 2013.

35. Susan Hornung, e-mail correspondence, March 28, 2013.

36. Carolyne Myall, "From the President," ALCTS Newsletter Online 24, no. 1 (2013), available online at www.ala.org/alcts/ano/v24/n1/president [accessed 30 June 2015].

37. Steinhoff, e-mail correspondence

38. Ibid.

39. Ibid.

40. Report from LITA Publications Committee, 2-3.

41. Pixey Mosley and Wendi Arant-Kaspar, "LLAMA News Section," Library Leadership E

Management 23, no. 1 (2009): 52, available online at https://journals.tdl.org/llm/index.php/llm/ article/view/1759/1039 [accessed 30 June 2015].

42. Arant Kaspar, "Walking the Talk," 2.

43. Ibid.

44. Hornung, e-mail correspondence.

45. Sara Arnold-Garza, Regina Gong, Nathan Hall, and Yasmeen Shorish, "Developing a Financially Sustainable Business Model for Library Resources and Technical Services (LRTS), the Official Journal of ALCTS," poster presented at the American Library Association Emerging Leaders session, Chicago, Ill., June 2013, available online at https://vtechworks.lib.vt.edu/ handle/10919/23249 [accessed 4 May 2015]. 
ALA Division Publications, Open Access, and Sustainability 667

46. Genevieve S. Owens and Mary Beth Weber, "An Open Letter to ALCTS Members and LRTS Subscribers," Library Resources and Technical Services 58, no. 2 (2104): 83, doi:10.5860/lrts.58n2.83.

47. "Division Committee and Interest Group Reports, Annual 2014," ALCTS News (Aug. 1, 2014), available online at www.ala.org/alctsnews/reports/ac2014-division [accessed 30 June 2015].

48. Elfenbein, "Cultural Anthropology," 289-90.

49. Arant Kaspar, "Walking the Talk," 2.

50. Elfenbein, "Cultural Anthropology."

51. American Library Association Council, "Core Values of Librarianship," American Library Association (last modified June 29, 2004), available online at www.ala.org/advocacy/intfreedom/ statementspols/corevalues [accessed 9 January 2015].

52. Vandergrift and Bowley, "Librarian, Heal Thyself"; ACRL Scholarly Communication Listserv, available online at http://lists.ala.org/sympa/arc/scholcomm/2014-10/msg00083.html [accessed 7 October 2015].

53. Shan C. Sutton, e-mail correspondence, May 26, 2015.

54. Mosley and Arant Kaspar, "Editors Introduction," 1; Cuddy, "President's Message: Open Access/Open Data," 2; Branin, "College and Research Libraries Goes Fully Open Access," $108-09$.

55. Matthew Cockerill, "Business Models in Open Access Publishing," in Open Access: Key Strategic, Technical and Economic Aspects, ed. Neil Jacobs (Oxford, U.K.: Chandos Publishing, 2006); Mangiafico and Smith, "Reason, Risk, and Reward," 219. 